\title{
PERAN GURU DALAM PENGGUNAAN MEDIA PEMBELAJARAN BERBASIS TEKNOLOGI INFORMASI DAN KOMUNIKASI (TIK) STUDI KASUS DI TK MUSLIMAT NU MASLAKUL HUDA
}

\author{
M. Ghofar Rohman, Purnomo Hadi Susilo \\ m.ghofarrohman@unisla.ac.id, hadyjelak.purnomo@gmail.com \\ Teknik Informatika, Fakultas Teknik, Universitas Islam Lamongan
}

\begin{abstract}
Abstrak
Dalam proses pembelajaran peran guru bertugas mendidik, mengajar, membimbing, mengarahkan, menilai, dan diakhiri dengan mengevaluasi pada peserta didiknya. proses pembelajaran dapat berjalan dengan baik dengan memperhatikan dua hal yaitu metode pembelajaran dan media pembelajaran. Penggunaan media pembelajaran diharapkan dapat membawa peran seorang guru untuk bisa lebih inovatif dan produktif dalam menyajikan materi yang disampaikan kepada siswa di kelas. Pemanfaatan TIK dalam media pembelajaran diharapkan memiliki kontribusi dan inovasi yang besar pada dunia pendidikan. Adanya TIK diharapkan dapat memberikan kemudahan bagi guru dalam meningkatkan kemampuan mengajarnya didalam kelas. Metodologi penelitian ini adalah deskriptif kualitatif. Dalam penelitian ini dilakukan wawancara mendalam (in deep-interview), pengamatan dan studi kepustakaan. Teknik cuplikannya menggunakan purposive sampling. Teknik analisis data dalam penelitian ini dengan menggunakan langkah-langkah reduksi data, penyajian data, dan penarikan kesimpulan. Hasil penelitian ini adalah guru di TK Muslimat NU Maslakul Huda sudah dapat melaksanakan proses pembelajaran dengan menggunakan media pembelajaran berbasis Teknologi Informasi dan Komunikasi. Guru berperan sangat besar dalam kelangsungan pembelajaran berbasis TIK. Peran guru ini didukung pula oleh adanya fasilitas penunjang sarana dan prasarana dengan memperbanyak media pembelajaran berbasis TIK di sekolah.
\end{abstract}

Kata Kunci: Guru, TIK, Media pembelajaran

\section{PENDAHULUAN}

Guru adalah pendidik profesional dengan tugas utama mendidik, mengajar, membimbing, mengarahkan, melatih, menilai, dan mengevaluasi peserta didik pada pendidikan anak usia dini jalur pendidikan formal, pendidikan dasar, dan pendidikan menengah (UU RI Nomor 14 Tahun 2005 Tentang Guru dan Dosen). Dalam proses kegiatan pembelajaran, selain guru ada dua unsur yang amat penting, yaitu metode pembelajaran yang digunakan dan media pembelajaran yang diimplementasikan dalam pembelajaran. Agar proses belajar mengajar terlaksana dengan baik, penggunaan metode dan media pembelajaran yang tepat tentunya sangat diperlukan. Kesesuaian metode pembelajaran dan media pembelajaran yang digunakan, proses pembelajaran akan lebih hidup dan dapat menjalin kerjasama diantara siswa, proses pembelajaran dimana guru menjadi pusat pembelajaran dapat dikurangi dengan penggunaan media pembelajaran yang dapat meningkatkan kreativitas siswa dalam berpikir, juga membuat arah kegiatan pembelajaran yang lebih kompleks tidak hanya satu arah sehingga proses belajar mengajar akan dapat meningkatkan kerjasama diantara siswa dengan guru dan siswa dengan siswa.

Pada dasarnya peningkatan proses pembelajaran tidak akan lepas dari peran guru sebagi fasilitor yang membawa konsekuensi terhadap perubahan pola hubungan guru siswa, yang semula lebih bersifat atasan bawahan beralih menjadi hubungan kemitraan. Hal ini sesuai dengan pendapat Sanjaya (2006) menjelaskan bahwa sebagai fasilitator, guru berperan dalam memberikan pelayanan untuk memudahkan siswa dalam kegiatan proses pembelajaran, sehingga siswa bisa lebih aktif dan kreatif. Hubungan kemitraan yang dijalin antara guru dengan siswa, disini guru bertindak sebagai pendamping belajar dengan suasana belajar yang demokratis serta menyenangkan. Upaya yang dapat dilakukan yaitu dengan 
memafaatkan media pembelajaran berbasis TIK pada proses pembelajaran, bukan untuk menggantikan peran guru melainkan sebagai alat bantu untuk guru dalam melaksanakan kegiatan pembelajaran.

Media pembelajaran tentunya membawa peran seorang guru untuk lebih inovatif dan produktif dalam menyajikan materi yang disampaikan kepada siswa di kelas. Media pembelajaran adalah perantara atau pengantar sebuah pesan yang diberikan kepada penerima pesan agar individu tersebut dapat melakukan kegiatan pembelajaran agar materi pembelajaran yang disampaikan dapat diterima secara baik oleh anak (Wardaya dan Sumartini, 2016). Sejalan dengan pendapat Karwati dan Priansa (2014) menjelaskan bahwa media pembelajaran merupakan sarana yang digunakan sebagai perantara untuk menyalurkan atau menyampaikan pesan kepada pihak lain atau peserta didik. Beberapa penjelasan diatas menjelaskan bahwa pemahaman tentang media pembelajaran yaitu alat atau segala sesuatu yang dapat digunakan untuk menyampaikan sebuah pesan kepada peserta didik.

Menjadi seorang guru harus pandai dalam memilih media pembelajaran yang dapat menjadi motivasi bagi siswa dan komunikatif dalam pembelajaran di kelas. Penggunaan TIK sebagai media pembelajaran tentunya memiliki kontribusi dan inovasi yang besar pada dunia pendidikan. Adanya TIK diharapkan dapat memberikan kemudahan bagi guru dalam meningkatkan kemampuan mengajarnya. Kreatifitas dan keterampilan guru dapat terlihat dari penggunaan media pembelajaran berbasis TIK. Guru dengan mudah mencari literatur dan informasi terkait dengan materi yang akan disajikan. Setelah dilakukan penelitian ini diharapkan guru dapat melaksanakan proses pembelajaran dengan menggunakan media pembelajaran berbasis TIK. Hal ini dilakukan karena peran guru dapat berpengaruh sangat besar dalam kelangsungan pembelajaran berbasis TIK. Peran guru ini didukung pula oleh adanya fasilitas penunjang sarana dan prasarana dengan memperbanyak media pembelajaran berbasis TIK di sekolah.

\section{METODE}

Metodologi penelitian ini adalah deksriptif kualitatif. Teknik pengumpulan data pada penelitian ini yaitu dengan melakukan wawancara, pengamatan dan studi kepustakaan. Teknik analisis data dalam penelitian ini adalah reduksi data, penyajian data dan kesimpulan.

\section{PEMBAHASAN}

Hasil temuan di TK Muslimat NU Maslakul Huda diketahui bahwa guru memiliki peranan yang penting dalam penggunaan media pembelajaran berbasis TIK. Hal ini dikarenakan guru yang menjadi tonggak utama dalam pelaksanaan pembelajaran di kelas. Pemahaman dan penguasaan guru tentang TIK sudah cukup dapat dipahami oleh guru. Akan tetapi, tidak semua guru beralih dari metode ceramah ke media pembelajaran berbasis TIK hal ini dikarenakan fasilitas dan sarana yang masih belum tercukupi di semua ruang kelas. Selain beberapa guru yang masih kesulitan dalam mengoperasikan komputer, laptop, LCD, audiovisual ataupun browsing internet hal ini tidak menyusutkan semangat para guru untuk menggunakan media pembelajaran berbasis TIK.

Hal ini juga didukung dari pernyataan Kusumah (2018) yang menyatakan bahwa pembelajaran yang menarik haruslah memfasilitasi siswa untuk berhasil mencapai tujuan pembelajaran secara optimal dengan cara yang mudah, cepat dan menyenangkan. Siswa di kelas pun menjadi lebih termotivasi dan antusias dalam 
pembelajaran di kelas dengan menggunakan media pembelajaran berbasis TIK. Siswa menjadi semangat dalam belajar, mencari ilmu dan informasi terkait yang disampaikan guru dan berpikir lebih luas.

Berdasarkan hasil observasi dan wawancara bahwa ada sebagian guru yang kesulitan dalam menggunakan media pembelajaran berbasis TIK hal ini dikarenakan durasi yang sangat singkat di kelas, fasilitas dan sarana yang masih minim di ruang kelas untuk penunjang pembelajaran berbasis TIK, sulitnya mengkondisikan siswa karena masih membutuhkan perhatian yang lebih khusus sehingga guru belum semuanya siap dalam menggunakan media pembelajaran berbasis TIK.

Dari uraian tersebut didukung oleh pernyataan Kusumah (2018) menyatakan bahwa teknologi yang tepat dilakukan dalam pembelajaran adalah dengan memanfaatkan alat yang dimiliki oleh guru atau sekolahnya. Jika yang dimiliki hanya berupa VCD maka guru tersebut dapat memanfaatkan VCD itu menjadi menarik. Sehingga dapat dikatakan bahwa teknologi yang terbaik dalam pembelajaran adalah guru dapat mengoperasikan alat atau benda (hasil dari penerapan teknologi informasi dan komunikasi) dengan cermat dan tepat. Jika di sekolah belum menunjang fasilitas seperti laptop, internet, maka hal ini tidak boleh menyurutkan kompetensi guru untuk menggunakan media pembelajaran berbasis TIK. Guru tidak perlu menunggu fasilitas dan sarana yang terpenuhi untuk menggunakan TIK dalam pembelajarannya. Sebab dengan Video, Film, VCD guru pun sudah bisa disebut menggunakan media pembelajaran berbasis TIK.

Media pembelajaran tentunya membawa peran seorang guru untuk lebih inovatif dan produktif dalam menyajikan materi yang disampaikan kepada siswa di kelas. Guru harus pandai dalam memilih media pembelajaran yang dapat menjadi motivasi bagi siswa dan komunikatif dalam pembelajaran di kelas. Penggunaan TIK sebagai media pembelajaran tentunya memiliki kontribusi dan inovasi yang besar pada dunia pendidikan. Dengan adanya TIK sangat memberikan kemudahan untuk guru dalam meningkatkan kemampuan mengajarnya. Kreatifitas dan keterampilan guru dapat terlihat dari penggunaan media pembelajaran berbasis TIK. Guru dengan mudah mencari literatur dan informasi terkait dengan materi yang akan disajikan pada kegiatan pembelajaran.

Guru di TK Muslimat NU Maslakul Huda sudah mulai menggunakan teknologi informasi, teknologi komputer dan internet. Meskpiun belum semua guru menggunakan media pembelajaran berbasis TIK dikarenakan kurangnya keterampilan dan penguasaan guru dalam menggunakan TIK pada kegiatan pembelajaran di kelas. Hal yang perlu ditingkatkan adalah kreativitas dan keterampilan guru untuk menggunakan TIK dalam pembelajarannya di kelas. Siswa sudah siap menerima TIK dalam pembelajaran di kelas hal ini dapat dilihat dari antusias siswa dalam menyimak dan memahami pembelajaran di kelas yang disampaikan oleh guru.

TIK adalah sebagai alat bantu yang digunakan guru dalam proses pembelajaran di kelas. Suatu alat tidak dapat berfungsi dengan baik jika guru tersebut tidak paham dan mampu secara kreatif untuk menggunakan alat tersebut untuk menjadi menarik dan bermanfaat dalam pembelajaran. Sehingga dibutuhkan keterampilan guru dalam penggunaan TIK agar tujuan pembelajaran tetap tercapai dengan menggunakan TIK.

Media pembelajaran adalah segala sesuatu yang dapat digunakan untuk menyalurkan pesan dan merangsang terjadinya proses belajar pada siswa (Aqib: 2017). TIK merupakan media yang tepat dalam menyampaikan pesan dan merangsang serta menstimulasi siswa untuk belajar. Dalam mempersiapkan 
media pembelajaran tentunya, guru harus mengetahui minat siswa dalam belajar di kelas dengan media pembelajaran yang mudah dilihat, menarik, sederhana tetapi bermanfaat bagi siswa. Media pembelajaran berbasis TIK yang melibatkan teks, gambar, suara dan video dapat menyajikan materi pelajaran lebih menarik dan tidak monoton serta mudah dalam penyampaiannya kepada siswa.

\section{Peran Guru dalam Pembelajaran Berbasis TIK}

Guru TK Muslimat NU Maslakul Huda yang melaksanakan pembelajaran berbasis TIK telah menjalankan tugas secara professional sebagai agen pembelajaran, Guru sebagai agen pembelajaran berperan memfasilitasi siswa agar dapat belajar secara nyaman dan dengan mudah berhasil menguasai kompetensi yang sudah ditentukan. Sejalan dengan pendapat Sanjaya (2006) "Sebagai fasilitator, guru berperan dalam memberikan pelayanan untuk memudahkan siswa dalam kegiatan proses pembelajaran. Pada dasarnya peran guru sebagi fasilitor membawa konsekuensi terhadap perubahan pola hubungan guru siswa, yang semula lebih bersifat atasan bawahan kehubungan kemitraan.

Dalam hubungan yang bersifat atasan dan bawahan, guru seringkali diposisikan sebagai atasan yang cenderung bersifat otoriter, instruksi bergaya birokrat. Sementara, siswa lebih diposisikan sebagai bawahan yang harus selalu patuh mengikuti instruksi dan segala sesuatu yang dikehendaki oleh guru. Berbeda dengan pola hubungan atasan bawahan, hubungan kemitraan antara guru dengan siswa, guru bertindak sebagai pendamping belajar para siswanya dengan suasana belajar yang demokratis dan menyenangkan. Hal ini dapat dicapai salah satunya dengan memafaatkan media pembelajaran berbasis TIK pada kegiatan pembelajaran, bukan untuk menggantikan peran guru melainkan sebagai alat bantu untuk guru dalam melaksanakan kegiatan pembelajaran.

Faktor-faktor yang mendukung penggunaan media pembelajaran berbasis TIK di TK Muslimat NU Maslakul Huda antara lain: pertama, adanya fasilitas yang memadai untuk digunakanya media pembelajaran berbasis TIK, hal ini dapat dilihat dari tersedianya peralatan pendukung TIK, seperti VCD, LCD Proyektor, dan Laptop. Kedua, dari pihak sekolah sangat mendukung adanya pelatihan Teknologi Informasi dan Komunikasi (TIK) bagi guru, baik kegiatan internal sekolah maupun kegiatan eksternal sekolah. Dan ketiga, diberlakukannya regulasi yang mendorong kemampuan guru dibidang TIK, hal ini diharapkan dapat mendorong guru untuk lebih aktif dan kreatif dalam mengembangkan kemampuan TIK mereka.

Selain ada faktor pendukung perlu juga dipaparkan adanya faktor penghambat yang menghambat penggunaan media pembelajaran berbasi TIK di TK Muslimat NU Maslakul Huda, antara lain: pertama, minimnya kemampuan guru dalam menggunakan perangkat TIK, utamanya dalam menggunakan komputer. Dan kedua, belum adanya jaringan internet disekolah yang dapat digunakan oleh guru untuk mengakses informasi tentang materi pembelajaran dan sebagainya.

\section{KESIMPULAN}

Guru di TK Muslimat NU Maslakul Huda memiliki peran yang penting dalam penggunaan media pembelajaran berbasis TIK. Hal ini karena guru yang langsung berinteraksi dengan siswa melakukan proses pembelajaran di kelas. Menggunakan media pembelajaran berbasis TIK tentunya akan meningkatkan kualitas, kreativitas dan profesionalisme guru dalam pengajaran. Pemahaman media pembelajaran berbasis TIK harus dipahami dan digunakan oleh semua guru di TK Muslimat NU Maslakul Huda karena 
sudah sangat wajib dilakukan di era globalisasi saat ini meskipun peran guru tidak dapat tergantikan dengan kehadiran TIK. TIK tidak dapat berfungsi dengan baik jika tidak digunakan dengan tepat oleh guru yang terampil.

Dukungan dari pihak-pihak terkait: kepala sekolah, komite sekolah dalam pengadaan sarana dan fasilitas yang memadai pembelajaran berbasis TIK sangat dibutuhkan agar tujuan pembelajaran dapat berjalan dengan maksimal ditengah kemajuan teknologi saat ini.

\section{DAFTAR PUSTAKA}

Aqib, Zainal. (2017). Model-Model Media dan Strategi Pembelajaran Kontekstual Inovatif, Bandung: Yrama Widya.
Karwati, E dan Priansa, D. (2014). Manajemen kelas. Bandung: Alfabeta.

Kusumah, Wijaya. ( 2018) Dalam Seminar Nasional Pendidikan Tantangan Menghadapi Era Teknologi Dalam Pendidikan Masa Kini, Aula Gedung PGRI Jakarta, 28 April 2018.

Sanjaya, Wina. (2006). Strategi Pembelajaran Berorientasi Standar Proses Pendidikan. Jakarta: Prenada Media Group.

UU RI Nomor 14 Tahun 2005 Tentang Guru dan Dosen

Wardaya, Cep Unang \& Sumartini, Tini. (2016). Media dan sumber belajar di TK. Bandung: PPPPK TK dan PLB. 